\title{
Produksi Fitoaleksin pada Tusam (Pinus merkusii Jungh. et de Vriese) sebagai Respon Infeksi Fungi Mikorisa
}

\section{The Production of Phytoalexins fromTusam (Pinus merkusii Jungh. et de Vriese) as Response to Mycorrhizal Fungi Infection}

\author{
S. Widyaningsih ${ }^{1}$, S.M. Widyastuti ${ }^{2}$ dan Sumardi $^{2}$ \\ 1. Loka Penelitian Tanaman-tanaman Jeruk dan Hortikultura Subtrofis, Pusat Penelitian dan Pengembangan \\ Hortikultura, Departemen Pertanian \\ 2. Laboratorium Perlindungan dan Kesehatan Hutan, Jurusan Budidaya Hutan, Fakultas Kehutanan UGM \\ e-mail: smwidyastuti@yahoo.com,*penulis untukkorespondensi
}

\begin{abstract}
The experiment aimed to detect (1) mycorrhizal infection induced phytoalexins production of the root of tusam and (2) its activity in suppressing a dumping off fungi, Fusarium sp and Rhizoctonia solani. Production of phytoalexins was detected from the extracts of mycorrhizal root of old trees and 4, 6 and 8 week-old seedlings in alcohol using a UV-spectrophotometer. The antifungal activity of phytoalexins was studied by inoculating the pathogenic fungi into mycorrhizal seedlings of tusam. The results showed that the spectra of phytoalexins of extracted mycorrhizal and nonmycorrhizal roots ranged from 203.2 to $204.6 \mathrm{~nm}$. Higher antifungal concentrations of antifungal compound was obtained from the root extracts of old trees and 4 week-old seedlings, indicated by the higher spectrophotometric absorbance $\left(0.315\right.$ and $0.324 \mathrm{~g}^{-1}$ root $\mathrm{ml}^{-1}$ ethanol), compared to that extracted from non-mycorrhizal root of the same plant origin. Mycorrhizal roots significantly suppressed the development of Fusarium sp. and Rhizoctonia solani.
\end{abstract}

Key words: phytoalexins, tusam, mycorrhiza

Diterima: 02 Juni 2005, disetujui: 27 Januari 2006

\section{Pendahuluan}

Tusam (Pinus merkusii Jungh. et de Vriese) merupakan salah satu jenis tanaman yang diusahakan secara intensif. Areal pertanaman tusam di Jawa Barat dan Jawa Timur masing-masing 474.987,4 dan 157.640,4 ha (Badan Planologi Kehutanan, 2002a; b). Tusam pada tingkat semai mengalami periode sukulen yang sangat panjang, menurut Baker (1950) dapat berlangsung sampai 25 hari. Pada saat itu, jaringan tanaman masih muda dan akar belum aktif sehingga rentan terhadap fungi patogen terutama fungi penyebab rebah semai (dumping off) seperti Fusarium sp. (Nair dan Sumardi, 2000).

Tusam mengadakan simbiosis dengan fungi tanah pembentuk mikorisa untuk meningkatkan penyerapan hara, khususnya fosfat, menghasilkan hormon untuk pertumbuhan tanaman (fitohormon), serta pengendalian fungi patogenik yang menyerang akar (Suvercha dan Mukerji, 1991; Jalali dan Jalali, 1991). Zak (1964) menyatakan bahwa peran fungi mikorisa, khususnya ektomikorisa dalam menekan timbulnya penyakit oleh patogen terbawa tanah antara lain dengan menstimulasi sel-sel akar selama simbiosis untuk membentuk penghambat kimia.

Penelitian ini bertujuan untuk mengetahui produksi fitoaleksin sebagai respon interaksi ektomikorisa pada tusam dan pengaruh inokulasi fungi mikorisa terhadap persentase infeksi mikorisa dan perkembangan Fusarium sp. dan Rhizoctonia solani. 


\section{Metode Penelitian}

\section{Isolat}

Inokulum fungi mikorisa diperoleh dari tanah bermikorisa di bawah tegakan tusam di Kaliurang yang didominasi oleh Russula sp. Isolat Fusarium sp. dan Rhizoctonia solani diisolasi dari semai tusam yang bergejala lanas dan diuji dengan Postulat Koch pada semai tusam.

\section{Ekstraksi fitoaleksin}

Ekstraksi fitoaleksin dilakukan dengan metode Nonaka dan Matsuzaki (1976) yang telah dimodifikasi. Akar pohon dan semai tusam bermikorisa dan tidak bermikorisa umur 4, 6 dan 8 minggu masing-masing sebanyak 10 gram digerus, kemudian diekstrak dengan 50 $\mathrm{ml}$ alkohol $70 \%$ dan dibiarkan semalam dalam keadaan tertutup. Ekstrak disaring dengan kertas saring dan diuapkan pada suhu $40^{\circ} \mathrm{C}$ sampai volumenya menjadi sepertiga dari volume semula kemudian ditambah air steril sampai tiga perempat volume semula. Fitoaleksin diekstrak dengan petrolium eter sebanyak 2 kali dengan $50 \mathrm{ml}$ dan $30 \mathrm{ml}$ petrolium eter, kemudian larutan bagian atas diambil dan bagian bawah dibuang. Hasil ekstraksi diuapkan dengan evaporator pada suhu $40^{\circ} \mathrm{C}$ sampai kering. Materi kering yang menempel pada dinding tabung evaporator disuspensikan dengan $5 \mathrm{ml}$ etanol absolut (100\%) dan disimpan pada suhu $4^{0}$ C. Crude fitoaleksin yang didapat diamati dengan spektrofotometer pada panjang gelombang 200-400 nm untuk mengetahui panjang gelombang, yang menunjukkan serapan maksimum ekstrak.

Semai tusam berumur 2 minggu dari bak perkecambahan, dipindahkan ke medium tanah bermikorisa dan tidak bermikorisa yang telah disiapkan, setiap bak berisi 25 semai. Empat hari setelah penanaman semai, bak diinokulasi dengan Fusarium sp. kerapatan $10^{6}$ spora $/ \mathrm{ml}$ sebanyak $100 \mathrm{ml} / \mathrm{bak}$ dan Rhizoctonia solani sebanyak 1 cawan Petri biakan/bak. Kematian semai setiap minggu diamati dan setelah 8 minggu dihitung persentasi infeksi mikorisa dengan menggunakan rumus.

Biota Vol. XI (2), Juni 2006

\section{Analisis hasil}

Sesuai dengan rancangan yang dibuat, data yang diperoleh dianalisis dengan analisis varians (ANOVA) dan uji lanjut (uji jarak Ganda Duncan) apabila terdapat perbedaan yang nyata.

\section{Hasil dan Pembahasan}

\section{Uji Patogenisitas}

Hasil uji patogenisitas menunjukkan bahwa isolat Fusarium sp. yang diisolasi dari semai tusam mempunyai virulensi yang tinggi sebagai penyebab penyakit rebah semai pada tusam. Pembusukan terjadi di minggu pertama, dimulai dari pangkal batang yang menyebabkan semai menjadi rebah. Biakan Fusarium sp. dalam PDA yang diperoleh berwarna putih, agak keungu-unguan mempunyai mikrokonidium yang berbentuk lonjong, hialin, bersekat atau tidak bersekat, berukuran $0,420 \mu \mathrm{m} \quad \mathrm{x} \quad 0,063 \mu \mathrm{m}$ dan makrokonidium yang berbentuk memanjang, hialin, berdinding tipis, terdiri 2-5 sekat yang agak tebal, berukuran $1,523 \mu \mathrm{m} \times 0,125 \mu \mathrm{m}$.

Gejala rebah semai yang disebabkan oleh Rhizoctonia solani terjadi mulai 6 minggu setelah semai dipindah ke bedeng sapih, mulai dari daun jarum yang berwarna hijau tua berubah menjadi coklat dan membusuk sampai pada bagian akar juga terjadi pembusukan. Semai ketika diisolasi menghasilkan biakan Rhizoctonia solani yang berwarna putih, kemudian berubah menjadi kecoklatan, hifa fungi bersekat-sekat, percabangan membentuk sudut siku-siku $\left(90^{\circ}\right)$, berlekuk pada bagian pangkalnya, hifa dapat menjadi gemuk, pendek dan berdinding tebal, sklerotium bentuknya tidak beraturan dan pipih.

\section{Analisis fitoaleksin}

Identifikasi suatu kandungan tumbuhan golongan senyawa dapat ditentukan dengan ciri spektrum UV. Nilai spektrum UV pada identifikasi kandungan yang tidak dikenal akan berkaitan dengan kerumitan nisbi spektrum dan letak umum panjang gelombang maksimal. Perbandingan identifikasi fenol dapat dilakukan dengan membandingkan spektrum UV-nya (Harborne, 1996). 

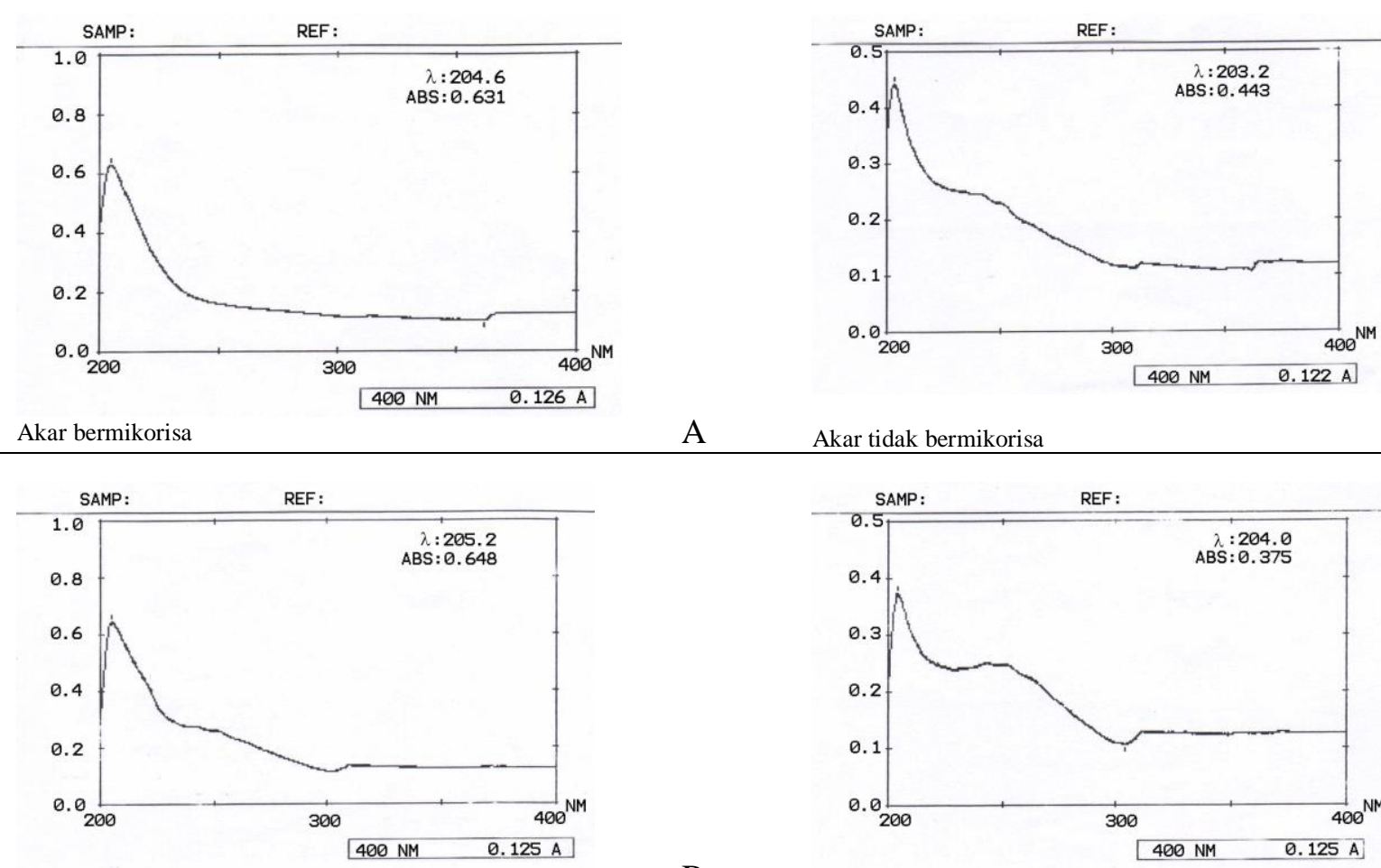

A

Akar tidak bermikorisa

Akar bermikorisa

B
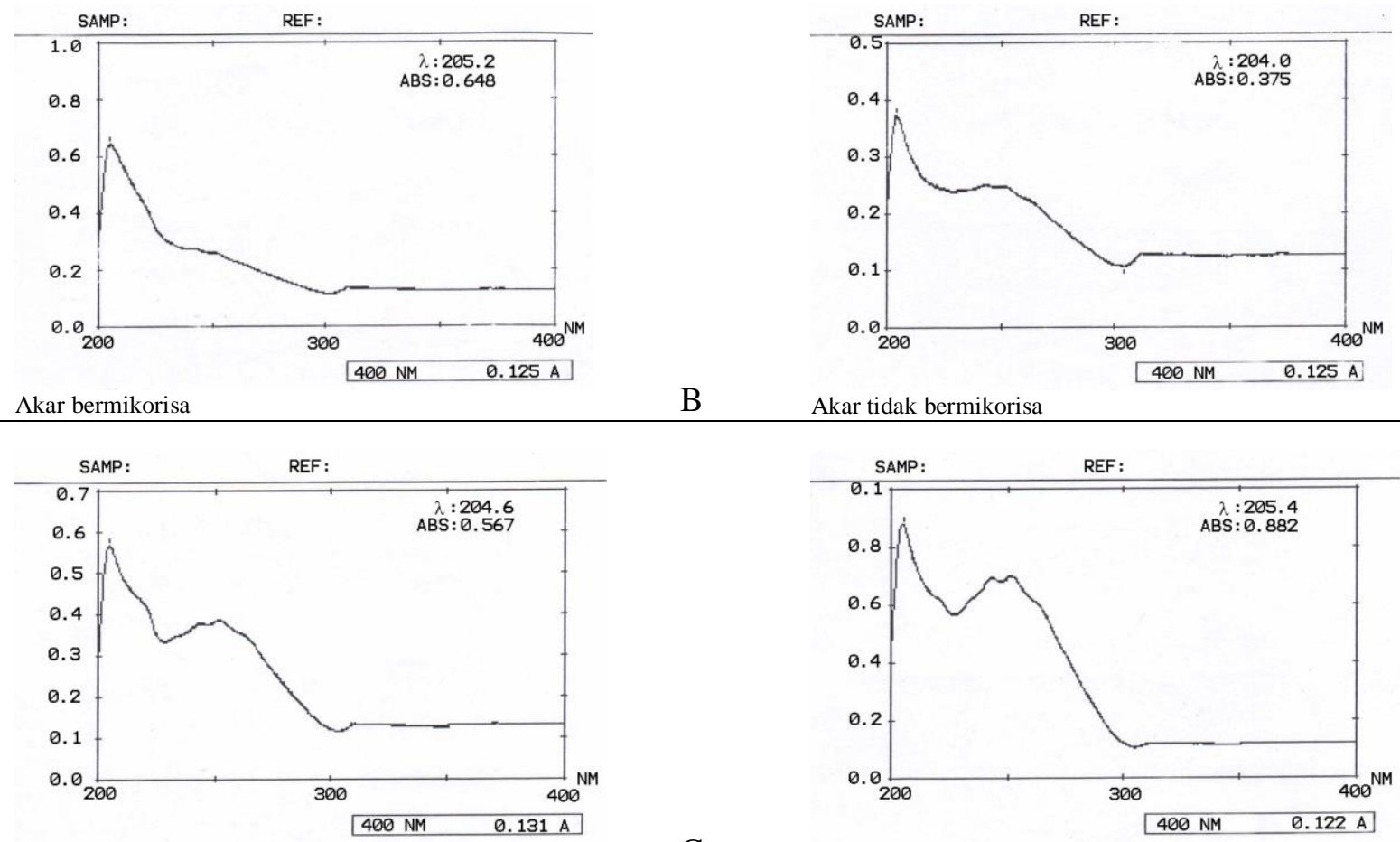

Akar tidak bermikorisa

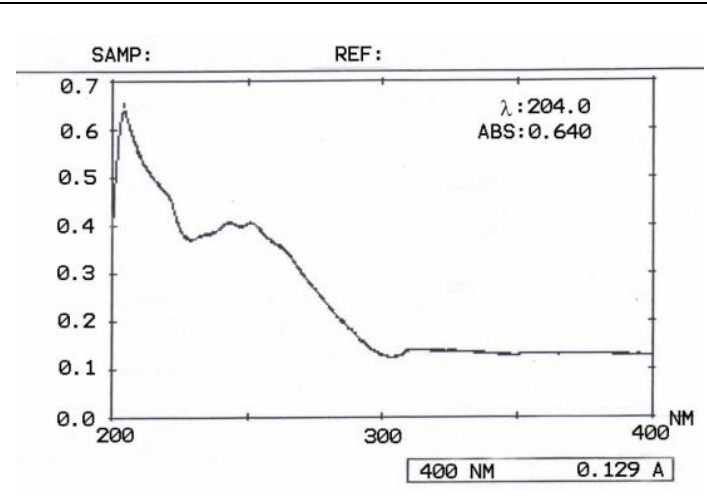

C

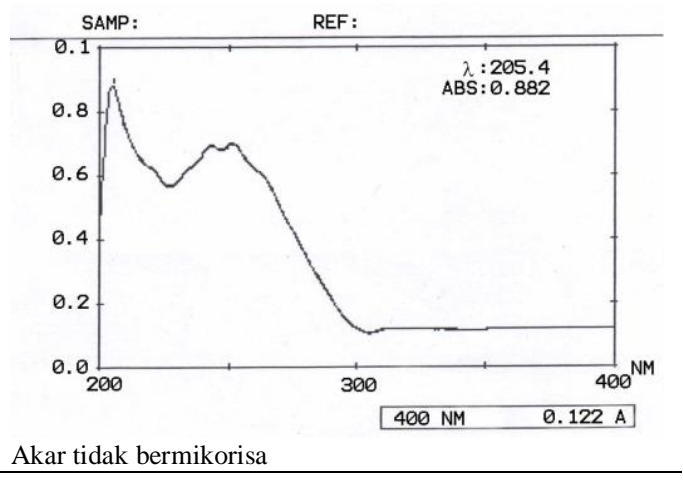

Akar bermikorisa

$\mathrm{D}$

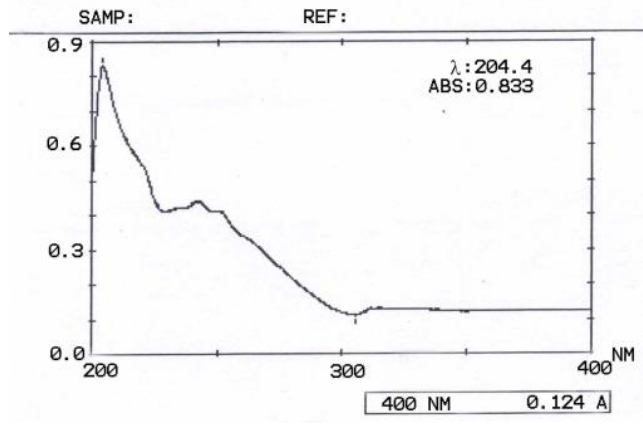

Akar tidak bermikorisa

Gambar 1. Spektrum-UV ekstrak fitoaleksin akar tusam (P. merkusii)

Keterangan : A. Akar pohon tusam tua; B. Akar semai tusam umur 4 minggu; C. Akar semai tusam umur 6 minggu; D. Akar semai tusam umur 8 minggu 
Akar tusam bermikorisa maupun tidak bermikorisa yang diekstrak baik yang bersumber dari pohon maupun semai tusam umur 4, 6 dan 8 minggu mempunyai spektrum yang hampir sama yaitu pada panjang gelombang (serapan maksimum) 203,2 nm 204,6 nm sehingga diduga merupakan jenis senyawa yang sama (Gambar 1). Hal ini menunjukkan bahwa tanaman telah memiliki pertahanan secara kimia atau memiliki kandungan senyawa fenolik sebelum diinfeksi oleh fungi mikorisa.

Gambar 1a dan 1b menunjukkan bahwa ekstrak dari akar pohon bermikorisa dan semai bermikorisa umur 4 minggu nilai serapan absorbansi yang lebih tinggi $(0,315$ dan 0,324 per gr akar/ml etanol) dari pada ekstrak akar tidak bermikorisa $(0,221$ dan 0,187 per gr akar/ml etanol). Peningkatan nilai serapan absorbansi fitoaleksin pada ekstrak akar bermikorisa diduga merupakan tanggapan tanaman terhadap infeksi fungi simbion dengan memproduksi atau meningkatkan konsentrasi senyawa penghambat (antifungal). Hal ini sesuai dengan hasil penelitian Marx (1972) bahwa infeksi akar Scot pine (Pinus sylvestris) oleh fungi simbion menghasilkan produksi dan akumulasi terpen dan sesquiterpen volatil dalam konsentrasi lebih dari 8 kali lebih besar dibanding di akar tidak bermikorisa.
Peningkatan konsentrasi fitoaleksin pada akar semai bermikorisa umur 4 minggu dapat juga terjadi karena adanya akumulasi fitoaleksin yang terbentuk akibat infeksi fungi mikorisa serta fitoaleksin yang terbentuk karena infeksi fungi Fusarium sp. penyebab penyakit rebah semai. Hal ini dapat dilihat dari fakta bahwa beberapa semai yang ditanam untuk diekstraksi, pada minggu pertama sampai minggu kedua mengalami kematian karena serangan Fusarium sp., sehingga diduga semai yang diekstraksi pada umur 4 minggu juga mendapat infeksi dari Fusarium sp. tetapi karena telah mendapat infeksi lebih dulu oleh fungi mikorisa dan terbentuk fitoaleksin sehingga tidak mengalami kematian. Hasil ini menunjukkan bahwa fitoaleksin merupakan salah satu penyebab terhindarnya semai dari penyakit rebah semai yang disebabkan oleh Fusarium sp. Gambar 1c dan 1d menunjukkan bahwa nilai absorbansi semai umur 6 dan 8 minggu juga terlihat lebih tinggi pada ekstrak akar semai yang tidak bermikorisa.

\section{Pengaruh inokulasi fungi mikorisa terhadap persentase infeksi mikorisa dan perkembangan fungi patogen}

Semai tusam umur 8 minggu yang diinokulasi dengan tanah bermikorisa menunjukkan persentase infeksi mikorisa yang cukup tinggi (Tabel 1).

Tabel 1. Nilai rerata persentase infeksi fungi mikorisa semai tusam ( $P$. merkusii) umur 8 minggu setelah diinokulasi fungi mikorisa dan patogen

\begin{tabular}{llcr}
\hline \hline \multicolumn{1}{c}{ Sumber variasi } & & Rerata $\left.(\%)^{*}\right)$ & SD \\
\hline \hline & $\mathrm{P}_{0}$ & 3,81 & 3,43 \\
Tanah tidak bermikorisa & $\mathrm{P}_{1}$ & 4,60 & 4,55 \\
& $\mathrm{P}_{2}$ & 5,41 & 4,79 \\
\multirow{2}{*}{ Tanah bermikorisa } & $\mathrm{P}_{0}$ & 27,62 & 20,10 \\
& $\mathrm{P}_{1}$ & 24,70 & 13,19 \\
& $\mathrm{P}_{2}$ & 19,86 & 3,19 \\
\hline \hline
\end{tabular}

Keterangan : $\mathrm{P}_{0}$ : tanpa patogen $; \mathrm{P}_{1}:$ Fusarium $\mathrm{sp} . ; \mathrm{P}_{2}:$ R. solani

\section{${ }^{*}$ tiga kali ulangan}

Semai yang tidak ditanam pada tanah bermikorisa, menunjukkan adanya infeksi mikorisa meskipun persentasenya kecil. Hal ini karena spora fungi mikorisa yang berukuran mikroskopik mudah tersebar dengan perantaraan angin, hujan, serangga dan binatang kecil (Marx dan Kenney, 1982). Menurut Brundrett et al. (1996) spora fungi Biota Vol. XI (2), Juni 2006 ektomikorisa mempunyai ukuran yang bervariasi, kurang lebih $4 \mu \mathrm{m}-30 \mu \mathrm{m}$ (biasanya berkisar antara $8 \mu \mathrm{m}-15 \mu \mathrm{m})$. Mudahnya spora menyebar menyebabkan kesulitan untuk menghalangi terbentuknya mikorisa jika terdapat tanaman di dekatnya yang sudah bermikorisa (Hadi, 1989). Selain itu tingkat infeksi dipengaruhi oleh banyak faktor seperti 
$\mathrm{pH}$, suhu, intensitas penyinaran dan kesuburan tanah. Nilai $\mathrm{pH}$ optimum untuk keberhasilan infeksi adalah $\mathrm{pH}$ agak asam dengan suhu sekitar 20-25 C (Marschner, 1986).

Pengaruh inokulasi fungi mikorisa terhadap perkembangan patogen penyebab rebah semai diamati berdasarkan persentase kematian semai tusam yang diinokulasi dengan Fusarium sp. dan Rhizoctonia solani. Persentase kematian semai tusam umur satu sampai delapan minggu dapat dilihat pada Gambar 2 dan 3.

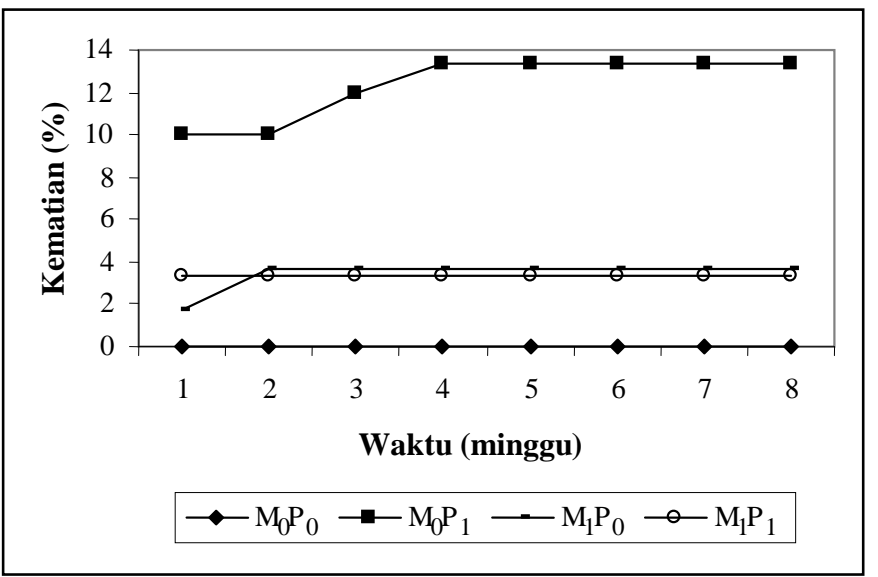

\footnotetext{
Gambar 2. Persentase kematian semai tusam (P. merkusii) yang diinokulasi Fusarium sp.

Keterangan : Mo : tanpa mikorisa Po : tanpa Fusarium sp. $\mathrm{M}_{1}$ : dengan mikorisa $\mathrm{P}_{1}$ : dengan Fusarium $\mathrm{sp}$.
}

Hasil pengamatan persen kematian semai tusam yang diinokulasi fungi mikorisa dan Fusarium sp. dari yang tertinggi hingga terendah adalah $\mathrm{M}_{0} \mathrm{P}_{1}(13,33 \%), \mathrm{M}_{1} \mathrm{P}_{0}(3,67 \%)$, $\mathrm{M}_{1} \mathrm{P}_{1}(3,33 \%)$, dan $\mathrm{M}_{0} \mathrm{P}_{0}(0 \%)$. Kematian semai terjadi sampai minggu keempat, yaitu pada $\mathrm{M}_{0} \mathrm{P}_{1}$.

Berdasarkan data spektrum-UV akar semai tusam tidak bermikorisa umur 4 minggu mempunyai kandungan fitoaleksin yang lebih rendah $(0,187$ per gram akar/ml etanol) dibanding ekstrak fitoaleksin dari akar semai tusam bermikorisa $(0,324$ per gram akar/ml etanol). Kematian semai yang terjadi sampai minggu keempat pada perlakuan $\mathrm{M}_{0} \mathrm{P}_{1}$ menunjukkan bahwa konsentrasi fitoaleksin pada akar semai tusam tidak bermikorisa umur 4 minggu belum mampu mencegah perkembangan Fusarium sp. Ketahanan terhadap penyakit terjadi jika kandungan fitoaleksin mencukupi untuk membatasi perkembangan patogen (Bailey, 1983), tetapi jika konsentrasinya terlalu tinggi juga akan meracuni tanaman itu sendiri, sehingga produksi fitoaleksin hanya merupakan salah satu mekanisme akar bermikorisa dalam meningkatkan ketahanan terhadap penyakit.

Dari gambar 3 diketahui bahwa inokulasi semai tusam dengan fungi mikorisa dan Rhizoctonia solani, mempunyai nilai persen kematian tertinggi pada $\mathrm{M}_{0} \mathrm{P}_{2}(16,67 \%)$, diikuti $\mathrm{M}_{1} \mathrm{P}_{2}(4 \%), \mathrm{M}_{1} \mathrm{P}_{0}(3,67 \%)$ dan $\mathrm{M}_{0} \mathrm{P}_{0}(0 \%)$. Pada $\mathrm{M}_{0} \mathrm{P}_{2}$ proses kematian terjadi sampai tujuh minggu.

Berdasarkan data spektrum-UV pada akar bermikorisa, semai umur 6 minggu dan 8 minggu mempunyai kandungan fitoaleksin yang lebih rendah dibandingkan dengan akar semai tidak bermikorisa. Tetapi perkembangan penyakit rebah semai yang disebabkan oleh Rhizoctonia solani pada akar bermikorisa relatif rendah dibanding dengan akar tidak bermikorisa. Hal ini diduga karena aktifnya mekanisme perlindungan ektomikorisa yang lain dalam menghadapi serangan Rhizoctonia solani. Hasil penelitian terdahulu (Anggoro et al. 2005; Handayani et al. 2005) menunjukan bahwa infeksi fungi mikorisa akan merangsang pembentukan kitinase dan 1-3 $\beta$ glukosa yang keduanya mempunyai aktivitas antifungal. 


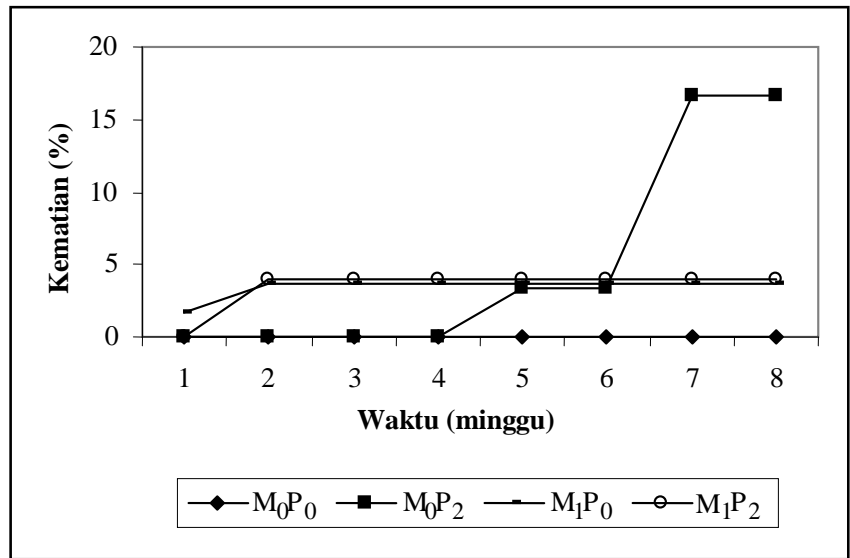

Gambar 3. Persentase kematian semai tusam (P. merkusii) yang diinokulasi Rhizoctonia $R$. solani

Keterangan : Mo : tanpa mikorisa Po : tanpa R. Solani $\mathrm{M}_{1}$ : dengan mikorisa $\mathrm{P}_{2}$ : dengan $\mathrm{R}$. solan

Persentase kematian semai yang diinokulasi Fusarium sp. maupun Rhizoctonia solani pada tanah tidak bermikorisa lebih tinggi dibandingkan pada tanah bermikorisa (Gambar 2 dan 3). Hal ini menunjukkan bahwa fungi mikorisa mampu melindungi semai tusam terhadap serangan patogen. Jalali dan Jalali (1991) berpendapat bahwa semai pohon bermikorisa mempunyai ketahanan terhadap infeksi akar oleh patogen potensial. Menurut Zak (1994) dan Duchesne (1996) perlindungan terhadap patogen tersebut disebabkan antara lain oleh penghambatan kimia yang dikeluarkan akar selama simbiosis, perlindungan mikroorganisme daerah rhizosfer yang bersifat protektif dan barier fisik (mantel), yang akan menyebabkan patogen menjadi lebih sulit menginfeksi dan berkembang pada akar bermikorisa dibandingkan dengan akar tidak bermikorisa.

Keberadaan fungi mikorisa juga akan menyebabkan kesehatan tanaman menjadi lebih baik karena mikorisa juga mampu menghasilkan zat-zat biokimia yang bersifat antagonistik terhadap penyakit tumbuhan. Darusman et al. (1994) melaporkan bahwa mekanisme jenis Scleroderma collumnare dan Rhizopogon sp. bersifat antagonistik terhadap fungi Fusarium dan Rhizoctonia sp.. Serangan $F$. solani dan Rhizoctonia solani terhadap $P$. massoniana yang berasosiasi dengan fungi mikorisa Suillus grevillei dan Boletus sp. menurun.
Kemampuan antagonisme fungi ektomikorisa ini menurut penelitian Zengpu et al. (1994) secara in vitro terdiri atas kemampuan antagonisme karena mengeluarkan senyawa volatil dan non volatil serta parasitisme fungi patogen oleh fungi mikorisa. Pengaruh senyawa volatil dan non volatil itu tidak hanya menimbulkan kerusakan hifa tetapi juga mempengaruhi pembentukan struktur reproduktif (konidia dan sporangia) dan juga menghambat perkecambahan spora.

\section{Kesimpulan}

1. Akar tusam (P. merkusii) bermikorisa maupun tidak bermikorisa menghasilkan senyawa fitoaleksin yang mempunyai spektrum yang sama pada panjang gelombang antara 203,2 $\mathrm{nm}$ sampai 204,6 nm.

2. Inokulasi fungi mikorisa meningkatkan persentase infeksi mikorisa dan menekan perkembangan Fusarium sp. dan Rhizoctonia solani.

\section{Ucapan Terima kasih}

Ucapan terima kasih ditujukan kepada Proyek Hibah Bersaing Perguruan Tinggi X tahun anggaran 2003 (No. Kontrak : 18/P2IPT/DPPM/PHBL/III/2003 tanggal 27 Maret 2003) yang telah memberikan dananya sehingga penelitian dapat berlangsung. 


\section{Daftar Pustaka}

Anggoro, M.D., Widyastuti, S.M. dan Margino, S. 2005. Isolasi dan Karakterisasi $\beta-1,3$-Glukanase Akar Semai Tusam (Pinus merkusii Jungh. et de Vriese) yang Berasosiasi dengan Jamur Mikorisa Ekto. J. Perlind. Tan. Indonesia 11(1).

Badan Planologi Kehutanan. 2002a. Data dan Informasi Kehutanan Propinsi Jawa Barat. Pusat Inventarisasi dan Statistik Kehutanan, Badan Planologi Kehutanan, Departemen Kehutanan.

Badan Planologi Kehutanan. 2002b. Data dan Informasi Kehutanan Propinsi Jawa Timur. Pusat Inventarisasi dan Statistik Kehutanan, Badan Planologi Kehutanan, Departemen Kehutanan.

Baker, S.F. 1950. Principles of Silviculture. Mc Graw Hill Book Company. New York. 651p.

Bailey, J.A. 1983. Biological Perspectives of HostPathogen Interactions. in: Bailey, J.A. dan B.J. Deverall. (Eds.). The Dynamics of Host Defence, pp. 233, Academic Press, New York.

Brundrett, M., Bougher, N., Dell, B., Grove, T. and Malajczuk, N. 1996. Working with Mycorrhizas in Forestry and Agriculture. ACIAR, Canberra.

Darusman, L.K., Fakuara, Y., Achmad, Nur, A. dan Moeljohardjo, D.S. 1994. The Screening of Bioactive Component from the Exudate of Ectomycorrhizal Fungus. dalam: Proceeding of Second Symposium on Biology and Biotechnology of Mycorrhizae and Third Asian Conference in Mycorrhizae (ACOM III). Yogyakarta, 19-24 April 1994.

Duchesne, L.C. 1996. Role of Ectomycorrhizae Fungi in Biocontrol. in: Pfleger, F.L. dan R.G. Linderman (Eds.). Mycorrhizae and Plant Health. APS Press. St. Paul, Minesota.

Hadi, S. 1989. Ekofisiologi Fungi. dalam: Patologi Hutan Perkembangannya di Indonesia, Fakultas Kehutanan IPB, Bogor.

Handayani, A., Widyastuti, S.M. dan Margino, S. 2005. Isolasi dan Karakterisasi Kitinase Akar Tusam (Pinus merkusii Jungh. et de Vriese) yang Bersimbiosis dengan Fungi Ektomikorisa. J. Perlind. Tan. Indonesia 11(2).
Harborne, J.B. 1996. Metode Fitokimia. Penuntun Cara Modern Menganalisis Tumbuhan. Terjemahan Padmawinata, K. dan I. Sudiro. ITB. Bandung.

Jalali, B.L. and Jalali, I. 1991. Mycorrhiza in Plant Disease Control. in: Arora D.K., B. Rai., K.G. Mukerji dan G.R. Knudsen. (Eds.). Handbook of Applied Mycology, Vol. 1 : Soil and Plants, Marcel Dekker Inc, New York.

Marx, D.H. 1972. Ectomycorrhizae as Biological Deterrents to Pathogenic Root Infections. Annual Rewiew of Phytopathology 10 : 429453.

Marx, D.H. and Kenney, D.S. 1982. Production of Ectomycorrhizal Fungus Inoculum. in: Schenck, N.C.(ed.). Methods and Principles of Mycorrhizal Research, pp. 131-145, The American Phytopathological Society, St. Paul, Minnesota.

Marschner, H. 1986. Mineral Nutrition of Higher Plants. Academic Press. San Diego.

Nair, K.S.S. dan Sumardi. 2000. Insect Pest and Diseases of Major Plantation Species. dalam: Nair, K.S.S.(ed.). Insect Pests and Diseases in Indonesia Forest: An Assessment of The Major Threats, Research Efforts and Literature, pp. 101, Center for International Forestry Research, Bogor.

Nonaka, F. and Matsuzaki, M. 1976. Production of Hydroxyphaseollin in Soybean Leaves Infected with the Blight Bacterium, Xanthomonas phaseoli var. sojae and Its Antifungal Action. Agricultural Bulletin of Saga University 40: 2.

Suvercha and Mukerji, K.G. 1991. Ectomycorrhiza. dalam: Arora D.K., B. Rai., K.G. Mukerji dan G.R. Knudsen. (Eds.). Handbook of Applied Mycology, Vol. 1 : Soil and Plants, pp. 187215, Marcel Dekker Inc, New York.

Zak, B. 1964. Role of Mycorrhizae in Root Disease. Ann.Appl.Biol. 44: 561.

Zengpu, L., Junran, J. and Changwen, W. 1994. Antagonism between Ectomycorrhizal Fungi and Plant Pathogens. dalam: Brundett, M., B. Dell., N. Malajczuk dan G. Mingqin .(Eds.). Mycorrhizas for Plantation Forestry in Asia. Proceedings of an International Symposium and Workshop. P.R. China. 7-11 November 1994. 